\title{
Fingerprinting of Some Petroleum Fractions Treated with Potassium Aluminium Sulphate
}

\author{
Inimfon A. Udoe tok ${ }^{*}$, Nye nime W. Akpanudo, Emaime J. Uwanta, Emmanuel E. Ubuo, \\ Emmanuel J. Ukpong
}

Chemistry Department, Akwa Ibom State University, Ikot Akpaden, Mkpat Enin Local Government Area, Akwa Ibom State, Nigeria

\begin{abstract}
This research investigates alteration in the composition of diesel and engine oil due to their treat ment with $35 \mathrm{~g}$ of Potassium Alu miniu m Sulphate, $\left(\mathrm{KAl}(\mathrm{SO} 4)_{2}\right)$ for seven days at room temperature. Results reveal that after treatment, the Total Petroleum Hydrocarbon (TPH) of diesel increased fro $\mathrm{m} 7688.38 \mathrm{mg} / 1$ to $12505.10 \mathrm{mg} / 1$ whereas that of engine oil increased from $4967.48 \mathrm{mg} / 1$ to $7700.47 \mathrm{mg} / \mathrm{l}$. This suggests that within these seven days, the salt was able to alter the composition of the samples by breaking down higher molecular weight hydrocarbon fractions within and above the C40 range to smaller mo lecular weight fractions with in the $\mathrm{C} 6$ to $\mathrm{C} 40$ range. The TPH of the treated diesel oil was similar to that of kerosene after treatment and that of the treated engine oil was similar to that of the untreated diesel sample. Ratios calculated from fingerprints of the samples such as $\mathrm{nC}_{20} / \mathrm{nC}_{24}, \mathrm{nC}_{18} / \mathrm{nC}_{24}, \mathrm{nC}_{18} / \mathrm{nC}_{20}, \mathrm{nC}_{7} / \mathrm{nC}_{9}$, and $\sum \mathrm{K} / \sum \mathrm{D}$ for the treated diesel samp le $(0.76,0.57,0.75,0.16$, and 0.84$)$ respectively were slightly similar to that of kerosene $(0.65,0.79,1.20,0.5$, and 1.08), but different from that of the untreated sample whereas ratios like $\mathrm{nC}_{10} / \mathrm{nC}_{11}, \mathrm{nC}_{11} / \mathrm{nC}_{12}, \mathrm{nC}_{14} / \mathrm{nC}_{16}, \mathrm{nC}_{11} / \mathrm{nC}_{20}$ and $\mathrm{nC}_{24} / \mathrm{nC}_{28}$ for the treated diesel sample $(0.53,0.35,1.02,0.67$ and 4.44) were similar to that of the untreated diesel sample $(0.52,0.36,0.92,0.46$ and 5.47). None of the ratios for the treated engine oil sample were similar to either those of the untreated engine oil sample or those of diesel. Therefore, though the treatment of the samples with $35 \mathrm{~g}$ of the salt caused alterations in the chemical composition of the samples, it did not totally transform them to the fraction obtained before them during distillation process.
\end{abstract}

Keywords Fingerprints, Diesel, Engine oil, Potassium Alu min ium Sulphate, TPH, Composition, Ratios

\section{Introduction}

The Concise Oxford dictionary defines Petroleum (L. petroleum, from Greek: petra (rock) + Latin: oleum (oil) or crude oil as a naturally occurring, flammable liquid consisting of a co mp lex mixture of hydrocarbons of various molecular weights and other liquid o rganic compounds, that are found in geologic formations beneath the Earth's surface[1]. Petroleum is recovered mostly through oil drilling. This latter stage comes after the studies of structural geology (at the reservoir scale), sedimentary basin analys is, and reservoir characterization (mainly in terms of porosity and permeable structures)[2],[3].

In its strictest sense, petroleum includes only crude oil, but in common usage it includes all liquid, gaseous, and solid (e.g., paraffin) hydrocarbons. Under surface pressure and temperature conditions, lighter hydrocarbons methane, ethane, propane and butane occur as gases, while pentane and heavier ones are in the form of liquids or solids.

* Corresponding author:

eeneemphorn@y ahoo.com (Inimfon A. Udoetok)

Published online at http://journal.sapub.org/chemistry

Copyright (C) 2012 Scientific \& Academic Publishing. All Rights Reserved
However, in an underground oil reservoir the proportions of gas, liquid, and solid depend on subsurface conditions and on the phase diagram of the petroleu m mixture [4], [5].

An oil well produces predominantly crude oil, with some natural gas dissolved in it. Because the pressure is lower at the surface than underground, some of the gas will come out of solution and be recovered (or burned) as as sociated gas or solution gas.

The proportion of light hydrocarbons in the petroleum mixture varies greatly among different oil fields, ranging from as much as $97 \%$ by weight in the lighter oils to as little as $50 \%$ in the heavier oils and bitumens. Whenit is refined and separated, most easily by boiling point, a large number of consumer products, from petrol, kerosene and diesel to lubricating oil, asphalt and chemical reagents used to make plastics and pharmaceuticals. Kerosene contains hydrocarbons with between 9 to 16 carbon atoms, diesel contains hydrocarbons with between 10 to 20 carbon atoms while engine oil contains hydrocarbons with between 24 to 38 carbon atoms [6].

The hydrocarbons in crude oil are mostly alkanes, cycloalkanes and various aromatic hydrocarbons while the other organic compounds contain nitrogen, oxygen and sulfur, and trace amounts of metals such as iron, nickel, 
copper and vanadium. The exact molecular compositionvaries widely from formation to formation but the proportions of chemical elements vary over fairly narrow limits as follows[7].

Four different types of hydrocarbon molecules appear in crude oil. These include: Paraffins, Naphthenes, Aromatics and Asphaltics. The relative percentage of each varies from oil to oil, determining the properties of each oil[5].

Potash alum (Potassium Aluminium Sulphate) is an inorganic salt with the molecular formula $\mathrm{KAl}\left(\mathrm{SO}_{4}\right)_{2}$. Potassium A lu min iu $\mathrm{m}$ Su lphate forms a solid, white powder at room temperature. It is a hygroscopic material which when exposed to air, hydrates (absorbs water). It is an important part of many products created by the pharmaceutical, cosmetic, and food industries because of its astringency property. It is also used in the manufacture of paper, dyes, glue, and explosives. Additionally, it helps in the water purification process, is used to speed up the hardening of concrete and plaster, and acts as a catalyst in various chemical reactions [8],[9].

Fingerprinting is a technique which involves the use of a gas chromatograph (GC -FID or GC-MS) for analysing samples for hydrocarbons fractions (TPH, PAH, and BTEX) present in them. This largely depends on the calibration of the equipment. A chromatogram which is obtained on completion of the analysis shows the components of the analysed sample and these components can be used in calculating various ratios. These ratios have a wide range of applications[10],[11].

In Akwa Ibom state, during scarcity of kerosene in the early nineties, diesel treated with Potassium Aluminium Sulphate was used as a substitute for kerosene. This paper therefore looks at the effect of treatment of diesel and engine oil with $35 \mathrm{~g}$ of Potassium Aluminium Sulphate, $\left.\mathrm{KAl}\left(\mathrm{SO}_{4}\right)_{2}\right)$ for seven days and also tries to ascertain if this treatment makes the samples similar to the fractions obtained before them during the distillation process. $35 \mathrm{~g}$ of the salt was chosen because reference [12] reported that it gave the best results in two days.

\section{Materials and Method}

\subsection{Sample Collection}

About $1000 \mathrm{ml}$ of Diesel oil was collected using a $500 \mathrm{ml}$ glass bottle from Onne port located in Port Harcourt, Rivers state, Nigeria while the inorganic salt, Kerosene and Engine oil were obtained from vendors in Uyo, A kwa Ibom State, Nigeria. On arrival at the laboratory, the diesel, kerosene and engine oil samples were stored in a refrigerator at $4^{\circ} \mathrm{C}$ till commencement of analyses while the Potash alum was stored in a cabinet.

\subsection{Sample Preparation}

Potash alum was dried at $80^{\circ} \mathrm{C}$ in the oven for about 12 hours. After drying the salt, it was kept in the desiccator for cooling before $35 \mathrm{~g}$ of the salt was introduced into $50 \mathrm{mls}$ of the diesel oil and engine oil in dry and clean $100 \mathrm{ml}$ bottles. The resulting mixtures were thoroughly shaken daily and allowed to react at room temperature in the Laboratory for seven days.

\subsection{Oil Extraction and Gas Chromatographic Analyses}

$1 \mathrm{~g}$ of each of the samples was weighed into well labeled clean and dry vialsand $10 \mathrm{mls}$ of pentane was added to them. The samples weighed stirred using a magnetic stirrer for about 5 minutes before they were allowed to concentrate to $1 \mathrm{ml}$.The extracts were fractionated into aliphatic fractions by adsorption liquid chromatography using a column of alumina and silica gel, while pentane was used as gradient solvent. The extracts were concentrated to $1 \mathrm{ml}$ and these were subjected to analyses[13],[14].

The TPH of the samples were determined using a Hewlett Packard 6890 gas chromatograph made by Agilent (USA) with the following operational conditions; flow rate $\left(\mathrm{H}_{2}\right.$ $30 \mathrm{ml} / \mathrm{min}$, air $300 \mathrm{ml} / \mathrm{min}$ and $\mathrm{N}_{2} 30 \mathrm{ml} / \mathrm{min}$ ), injection temperature $\left(50^{\circ} \mathrm{C}\right)$, detector temperature $\left(320^{\circ} \mathrm{C}\right)$. For signals, the GC was interfaced to a Hewlett Parker (hp) computer.

\section{Results and Discussions}

The treatment of the samples with $35 \mathrm{~g}$ of Potassium Aluminium Sulphate altered the total petroleu m hydrocarbon (TPH) of the samples within the seven days of treatment (table i). The results revealed that the TPH of the diesel increased from $7688.38 \mathrm{mg} / 1$ to $12505.10 \mathrm{mg} / 1$ whereas that of engine oil increased from $4967.48 \mathrm{mg} / 1$ to $7700.47 \mathrm{mg} / 1$. This suggests that within these seven days, the salt was able to breakdown higher molecular weight hydrocarbon fractions within and above the C40 range to smaller molecular weight fractions which fell within the C40 range. This is corroborated by the increment and decrement in the concentrations of some of the fractions andthe presence of C6 to $\mathrm{C} 12$ fractions in the fingerprints of the treated engine oil sample which was absent in the untreated engine oil sample. The similarity in the TPH of the treated engine oil and that of the untreated diesel also supports this. For instance, the concentration of the C6 and C18 fraction in the untreated diesel oil was $1711.61 \mathrm{mg} / 1$ and $1507.06 \mathrm{mg} / 1$ whereas after the treatment, it drastically reduced to $21.66 \mathrm{mg} / 1$ and $891.65 \mathrm{mg} /$ respectively, the difference between them being statistically significant at $95 \%$ confidence limit. On the contrary, the remaining fractions recorded increased concentrations. This also supports alteration in the composition of the sample. On looking at the total concentration of fractions within the diesel, engine oil and kerosene range in the samples, it revealed that the concentration of fractions in the kerosene range (table ii) for the treated diesel sample $(8247.0 \mathrm{mg} / \mathrm{l})$ was a little similar to that of kerosene $(11361.95 \mathrm{mg} / \mathrm{l})$ but very different fro $\mathrm{m}$ that of the untreated diesel sample(2347.26mg/1). Also, the concentration of fractions in diesel range for the treated 
engine oil sample was similar to that of the untreated sample. Statistical ana lys is (students' t-test) shows that the difference between the TPH of the treated diesel sample and that of kerosene was not significant at $95 \%$ confidence limit.For the treated engine oil sample, the result shows that the total concentration of fractions within the engine oil range $(6861.14 \mathrm{mg} / 1)$ was still similar to that of the untreated sample $(4349.52 \mathrm{mg} / \mathrm{l})$, thus suggesting that though the sample had undergone alterations in its composition, it still retained the characteristics of engine oil.

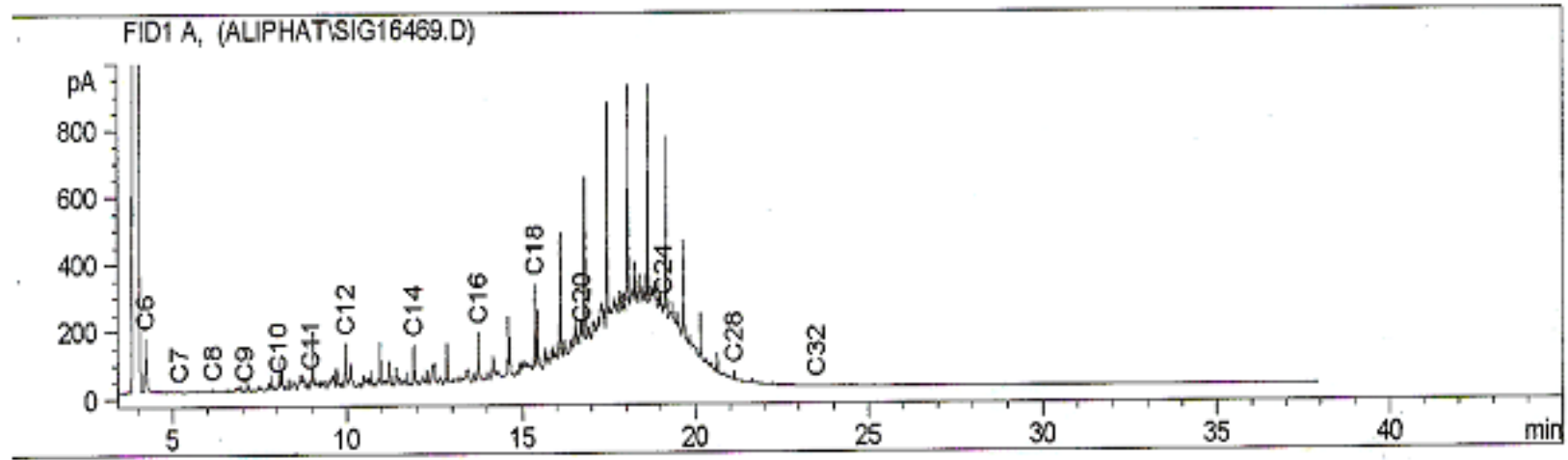

Figure 1. Fingerprint of diesel

Table 1. Effect of Potassium Aluminium Sulphate on some petroleum products

\begin{tabular}{|c|c|c|c|c|c|}
\hline Hydrocarbon fraction & $\operatorname{Diesel}(\mathrm{mg} / \mathrm{l})$ & Kerosene $(\mathrm{mg} / \mathrm{l})$ & Engine oil(mg/l) & Treated Engine oil & Treated Diesel \\
\hline $\mathrm{C} 6$ & 1712 & 40.33 & - & 32.35 & 21.66 \\
\hline $\mathrm{C} 7$ & 7.18 & 87.09 & - & 43.49 & 15.85 \\
\hline $\mathrm{C} 8$ & 50.66 & 88.05 & - & 157.4 & 221.5 \\
\hline $\mathrm{C} 9$ & 25.09 & 174.4 & - & 7.99 & 97.22 \\
\hline $\mathrm{C} 10$ & 130.4 & 694.1 & - & 37.99 & 420.0 \\
\hline $\mathrm{C} 11$ & 248.8 & 2697 & - & 83.93 & 791.9 \\
\hline $\mathrm{C} 12$ & 690.7 & 2044 & - & 12.00 & 2233 \\
\hline $\mathrm{C} 14$ & 612.2 & 5612 & 8.98 & 30.41 & 2378. \\
\hline $\mathrm{C} 16$ & 666.9 & 141.3 & 27.36 & 7.97 & 2327 \\
\hline $\mathrm{C} 18$ & 1507 & 6.81 & 149.56 & 157.4 & 891.7 \\
\hline $\mathrm{C} 20$ & 545.0 & 5.67 & 432.07 & 261.8 & 1187 \\
\hline $\mathrm{C} 24$ & 1258 & 8.66 & 1611 & 2668 & 1555 \\
\hline $\mathrm{C} 28$ & 229.8 & 24.96 & 953.4 & 2654 & 349.9 \\
\hline $\mathrm{C} 32$ & 4.74 & 2.62 & 1402 & 1137 & 12.43 \\
\hline $\mathrm{C} 36$ & - & 4.42 & 379.7 & 402.5 & 3.05 \\
\hline $\mathrm{C} 40$ & - & - & 3.79 & 6.62 & - \\
\hline Total & 7688 & 11631 & 4967 & 7700 & 12505 \\
\hline
\end{tabular}

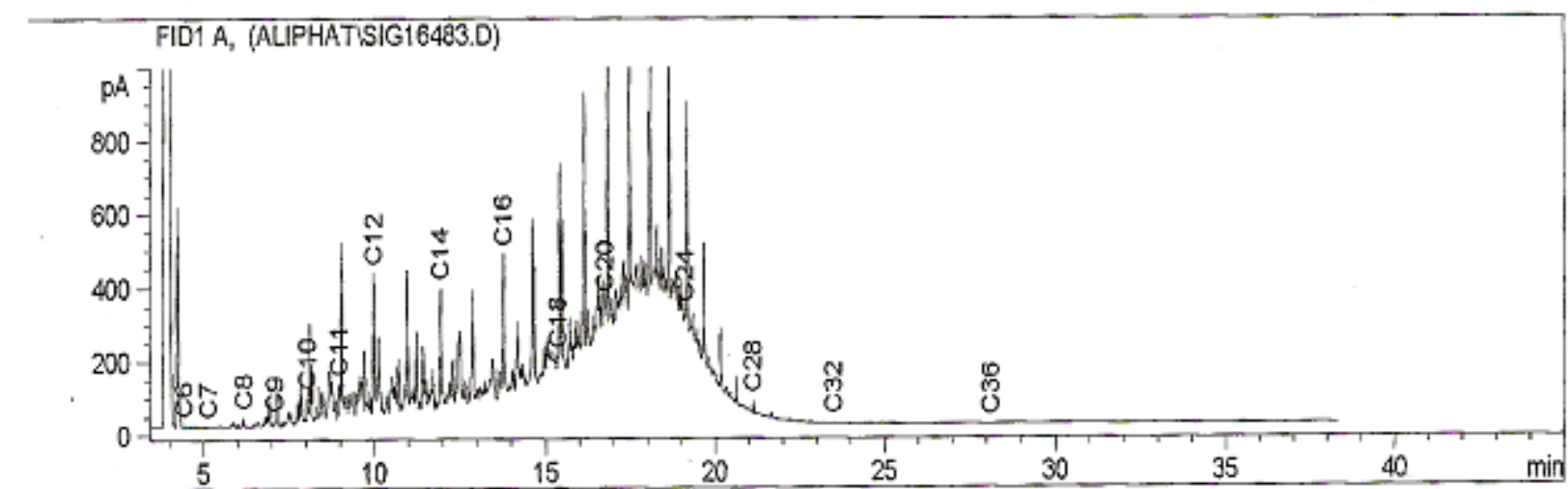

Figure 2. Fingerprint showing alteration in the composition of diesel after treatment with the salt 
The fingerprints of the samples (Fig. 1, Fig. 2 and Fig. 3) also confirm alterations in the composition of the samples though the alterations did not make it very similar to kerosene which is the fraction obtained before it during the distillation process. Of all the ratios calculated using the fingerprints of the samples, only few of them were slightly similar while one $\left(\mathrm{nC}_{9} / \mathrm{nC}_{16}=0.04\right)$ was the same for the untreated and treated diesel sample. The $\mathrm{nC}_{20} / \mathrm{nC}_{24}$, $\mathrm{nC}_{18} / \mathrm{nC}_{24}, \mathrm{nC}_{18} / \mathrm{nC}_{20}, \mathrm{nC}_{7} / \mathrm{nC}_{9}$, and $\sum \mathrm{K} / \sum \mathrm{D}$ ratios for the treated diesel sample (table 4 ) of $0.76,0.57,0.75,0.16$, and 0.84 respectively were slightly similar to that of kerosene $(0.65,0.79,1.20,0.5$, and 1.08$)$, but different from that of the untreated sample. These show that though the treated sample had not undergone enough alteration in composition to make it have the same properties as kerosene, it had some characteristics of kerosene. Reference[12] also reported that though the treatment of diesel with $35 \mathrm{~g}$ of Potassium
Aluminium Sulphate had effects on the physicochemical characteristics of diesel oil, the treated diesel oil cannot be used as kerosene. The similarities in the TPH of the two samples confirm this. On the contrary, ratios like $\mathrm{nC}_{10} / \mathrm{nC}_{11}$, $\mathrm{nC}_{11} / \mathrm{nC}_{12}, \mathrm{nC}_{14} / \mathrm{nC}_{16}, \mathrm{nC}_{11} / \mathrm{nC}_{20}$ and $\mathrm{nC}_{24} / \mathrm{nC}_{28}$ for the treated diesel sample $(0.53,0.35,1.02,0.67$ and 4.44$)$ were similar to that of the untreated diesel sample $(0.52,0.36,0.92,0.46$ and 5.47). These suggest that the treated diesel sample still had some characteristics of diesel[15]. On the contrary, for the engine oil, none of the ratios were similar to the ratios for either the untreated engine oil samp le or the untreated diesel sample. This therefore suggest that the engine oil had undergone enough alteration to make it different from the untreated engine oil but the alteration was not enough to make it exhibit some characteristics of diesel oil. The presence of peaks within the $\mathrm{C} 6$ to $\mathrm{C} 12$ region affirms this.

Table 2. Ratios of selected hydrocarbon fractions of the samples

\begin{tabular}{|c|c|c|c|c|c|c|}
\hline & & & Samples & & & \\
\hline $\mathrm{S} / \mathrm{N}$ & Ratios & Treated Diesel & Kerosene & Diesel & Treated Engine oil & Engine oil \\
\hline 1 & $\sum \mathrm{K} / \sum \mathrm{D}$ & 0.84 & 1.08 & 0.56 & 0.33 & 0.05 \\
\hline 2 & $\sum \mathrm{E} / \sum \mathrm{D}$ & 0.20 & 0.003 & 0.35 & 12.39 & 7.04 \\
\hline 3 & $\sum \mathrm{K}$ & 8247 & 11362 & 2347 & 180.3 & 36.34 \\
\hline 4 & $\sum \mathrm{D}$ & 9808 & 10506 & 4271 & 553.5 & 618.0 \\
\hline 5 & $\sum \mathrm{E}$ & 1921 & 40.66 & 1492 & 6861 & 4350 \\
\hline 6 & $\mathrm{nC}_{7} / \mathrm{nC}_{9}$ & 0.16 & 0.5 & 0.29 & 5.44 & - \\
\hline 7 & $\mathrm{nC}_{9} / \mathrm{nC}_{16}$ & 0.04 & 1.23 & 0.04 & 1.00 & - \\
\hline 8 & $\mathrm{nC}_{10} / \mathrm{nC}_{11}$ & 0.53 & 0.26 & 0.52 & 0.45 & - \\
\hline 9 & $\mathrm{nC}_{11} / \mathrm{nC}_{12}$ & 0.35 & 1.32 & 0.36 & 6.99 & - \\
\hline 10 & $\mathrm{nC}_{11} / \mathrm{nC}_{14}$ & 0.33 & 0.48 & 0.40 & 2.76 & - \\
\hline 11 & $\mathrm{nC}_{11} / \mathrm{nC}_{20}$ & 0.67 & 475.7 & 0.46 & 0.32 & - \\
\hline 12 & $\mathrm{nC}_{14} / \mathrm{nC}_{16}$ & 1.02 & 39.72 & 0.92 & 3.82 & - \\
\hline 13 & $\mathrm{nC}_{16} / \mathrm{nC}_{18}$ & 2.61 & 20.75 & 0.44 & 0.05 & 0.18 \\
\hline 14 & $\mathrm{nC}_{18} / \mathrm{nC}_{20}$ & 0.75 & 1.20 & 2.77 & 0.60 & 0.35 \\
\hline 15 & $\mathrm{nC}_{18} / \mathrm{nC}_{24}$ & 0.57 & 0.79 & 1.20 & 0.06 & 0.09 \\
\hline 16 & $\mathrm{nC}_{20} / \mathrm{nC}_{24}$ & 0.76 & 0.65 & 0.43 & 0.10 & 0.27 \\
\hline 17 & $\mathrm{nC}_{24} / \mathrm{nC}_{28}$ & 4.44 & 0.35 & 5.47 & 1.01 & 1.69 \\
\hline 18 & $\mathrm{nC}_{28} / \mathrm{nC}_{32}$ & 28.15 & 9.53 & 48.48 & 2.33 & 0.68 \\
\hline
\end{tabular}

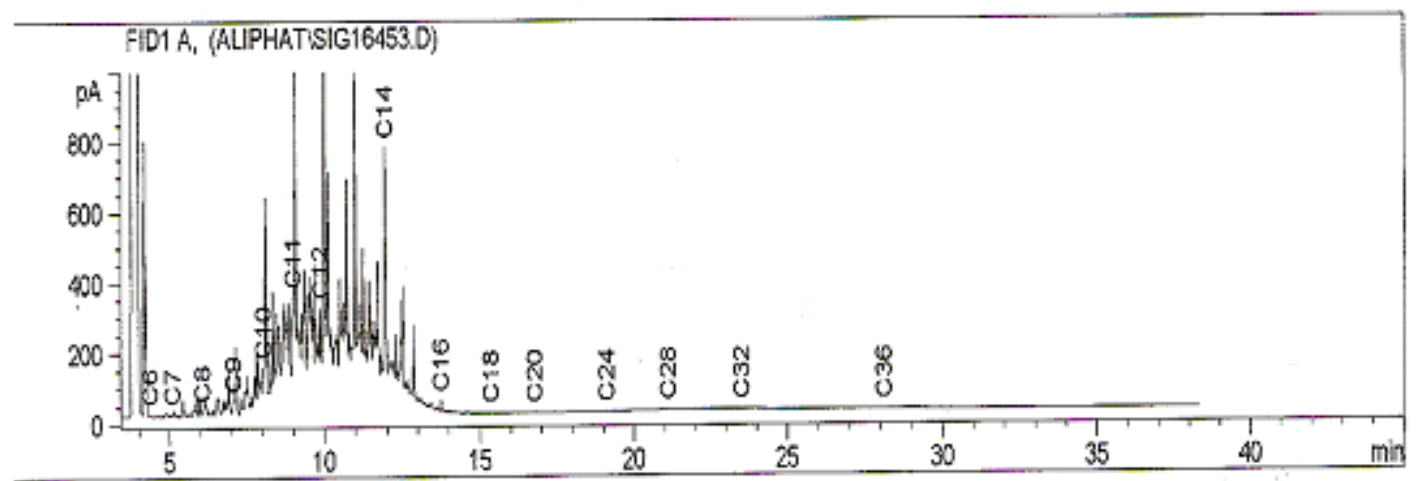

Figure 3. Fingerprint of Kerosene 


\section{Conclusions}

The results obtained from the analyses of samples of diesel and engine oil treated with $35 \mathrm{~g}$ of Potassium Aluminium Sulphate has shown that the treatment of the samples for seven days altered the TPH of the samples. So me of the fractions recorded increment in their concentrations whereas others had decreased concentrations. The C6 and $\mathrm{C} 18$ fractions drastically reduced after treatment of the diesel oil while the treated engine oil sample had peaks within the C6 to $\mathrm{C} 12$ region, though it was not present in the untreated sample. These suggest that the inorganic salt may have been able to breakdown (crack) the hydrocarbon fractions in the samples to fractions within above the $\mathrm{C} 6$ to $\mathrm{C} 40$ range, thus confirming the alteration in the composition of the samples. From the above, it could be concluded that though the treatment of the samples with the salt altered their compositions, the alteration was not enough to make the samples similar to the fractions obtained before them during the distillation process.

Where:

$\sum \mathrm{K}$ - sum of fractions within the kerosene range

$\sum \mathrm{D}$ - sum of fractions within the diesel range

$\sum E$ - sum of fractions within the engine oil range

\section{ACKNOWLEDGEMENTS}

The authors are grateful to the manage ment of Technology Partners International Nigeria Limited Port Harcourt for facilitating this research.

\section{REFERENCES}

[1] "Petroleum". Concise Oxford English Dictionary.

[2] Guerriero, V., Vitale, S., Ciarcia, S., and Mazzoli, S. Improved statistical multi-scale analysis of fractures in carbonate reservoir analogues. Tectonophysics. Elsevier 504:14-24.2011.

[3] Guerriero, V., Vitale, S., Ciarcia, S., and Mazzoli, S. Quantify ing uncertainties in multi-scale studies of fractured reservoir analogues: Implemented statistical analysis of scan line data from carbonate rocks. Journal of Structural Geology. Elsevier 32 (9): 1271-1278.2010.

[4] "Petroleum." en.wikipedia.org. 2011.http://en.wikipedia.org/ wiki/Petroleum (14 January 2012).

[5] Hyne, N. J. Nontechnical Guide to Petroleum Geology, Exploration, Drilling, and Production, PennWell, pp. $1-4.2001$.

[6] Ababio, O. Y. New School Certificate Chemistry. pp. 83, 84 and 113. Academy Press, Lagos, Nigeria. 1993.

[7] Speight, J. G. The Chemistry and Technology of Petroleum. Marcel Dekker. pp. 215-216. 1999.

[8] Bottomley, L. and Bottomley, L.A. School of Chemistry \& Bichemistry, Georgia Institute of Technology, Chemistry 1310: Laboratory Manual. Plymouth, MI: Hayden-McNeil Publishing. 2010.

[9] http://science.jrank.org/pages/5422/Potassium-Aluminum-Su lfate.html\#ixzzlibE3EqlR.

[10] Udoetok, I. A. and Osuji, L. C. Gas chromatographic fingerprinting of crude oil from Idu-Ekpeye oil spillage site in Niger-Delta, Nigeria. Environ. Monit. Assess. 141:359 - 364. 2008.

[11] Yang, Z. Z., Hollebone, B. P. B., Wang, Z. Z. Yang,C. C and Landriault,M. M. Method development for fingerprinting of biodiesel blends by solid-phase extraction and gas chromatography-mass spectrometry. Crossref 34(22):3253-64. 2011.

[12] Jimoh, A. The use of diesel oil treated with inorganic salt: an alternative to kerosene. $A U J . T .8$ (1): 27 - 34.2004.

[13] Osuji, L. C., Udoetok, I. A. and Ogali, R. E.Attenuation of Petroleum Hydrocarbons by weathering: A case study. Chem. \& Biodiv. 3: 422 - 433.2006 .

[14] Udoetok, I. A. Composition and Distribution of Petroleum Hydrocarbons of Idu-Ekpeye Oil Spillage site in Niger-Delta, Nigeria. M.Sc. Thesis, University of Port Harcourt, Nigeria. 2005.

[15] Wang, Z. Z.,Yang, C. C.,Yang, Z. Z., Sun, J. J.,Hollebone, B. B.,Brown, C. C., and Landriault,M. M. 2011.Forensic fingerprinting and source identification of the Sarnia (Ontario) oil spill.Crossref 13(11):3004-17.2009. 